\title{
Teknik Invisible Watermarking Digital Menggunakan Metode DWT (Discrete Wavelet Tarnsform)
}

\author{
Stephanie Gani dan Budi Setiyono \\ Departemen Matematika, Fakultas MIPA, Institut Teknologi Sepuluh Nopember (ITS) \\ e-mail: budi@matematika.its.ac.id
}

\begin{abstract}
Abstrak-Kemudahan penyebaran citra digital .melalui internet memiliki sisi positif dan negatif terutama bagi pemilik asli citra digital tersebut. Sisi positif dari kemudahan penyebaran adalah dengan cepatnya pemilik citra tersebut menyebarkan file citra digital ke berbagai alamat situs di dunia. Sedangkan sisi negatifnya adalah jika tidak ada hak cipta yang berfungsi sebagai pelindung citra yang disebarkan tersebut, maka citra digital ini, yang misalkan adalah hasil foto komersil, atau hasil karya lukisan digital, akan sangat mudah diakui kepemelikannya oleh pihak lain. Watermark merupakan salah satu solusi untuk melindungi hak cipta terhadap foto digital yang dihasilkan. Dengan diterapkannya Digital Image Watermarking ini maka hak cipta foto digital yang dihasilkan akan terlindungi dengan cara menyisipkan informasi tambahan seperti informasi pemilik, keaslian, dsb ke dalam foto digital tersebut. Discrete Wavelet Transform (DWT) merupakan salah satu kakas yang banyak digunakan dalam teknik watermarking dalam domain transform.
\end{abstract}

Kata Kunci-Citra Digital, Watermarking, Discrete Wavelet Transform (DWT).

\section{PENDAHULUAN}

$\mathrm{S}^{\prime}$ AAT ini penggunaan internet dalam kehidupan sehari hari menjadi hal yang umum. Banyak fasilitas yang ditawarkan di internet, salah satunya adalah unggah dan unduh file citra. Dengan adanya fasilitas unggah dan unduh file seseorang dapat mengunggah dan mengunduh file citra dengan mudah karena adanya jangkauan penggunaan internet yang sangat luas.

Penggunaan internet yang sangat luas ternyata memiliki sisi positif dan negatif terutama bagi pemilik asli citra digital. Sisi positif dari kemudahan penyebaran tersebut antara lain dengan cepatnya pemilik citra menyebarkan file citra digital ke salah satu situs yang ada di internet. Sedangkan sisi negatifnya antara lain tidak adanya perlindungan kepemilikan citra yang disebarkan, citra digital ini akan sangat mudah diakui kepemilikannya oleh pihak lain.

Berdasarkan kasus-kasus yang terjadi dalam pelanggaran hak cipta, khususnya dalam kasus pengakuan karya citra digital orang lain, pemberian watermarking menjadi hal yang sangat diperlukan. Pemberian watermarking bertujuan untuk melindungi data citra digital dari pengakuan orang lain.

Watermarking merupakan suatu proses penyisipan data/informasi tertentu ke dalam suatu data citra digital lainnya, tetapi tidak diketahui kehadirannya oleh indera manusia. Watermarking ini memanfaatkan kekurangankekurangan sistem indera manusia seperti mata dan telinga.
Informasi yang disisipkan kemudian harus dapat diperoleh kembali meskipun data digital telah didistribusikan. Saat distribusi citra akan menyebabkan turunnya nilai korelasi watermark yang diurai. Turunnya nilai korelasi watermark disebabkan penyisipan watermark dilakukan pada frekuensi tinggi atau bagian detail citra, dan noise yang mengkontribusikan komponen frekuensi tinggi citra. Dengan berkurangnya komponen frekuensi tinggi citra, maka informasi watermark yang disisipkan pada kawasan frekuensi tinggi citra secara otomatis akan berkurang juga.

Dengan berkembangnya watermarking pada saat ini, berkembang pula metode - metode yang di terapkan pada proses digital watermarking. Sebagai contoh, metode transformasi DWT (Discrete Wavelet Transform). DWT (Discrete Wavelet Transform) merupakan salah satu teknik pemrosesan sinyal digital. Teknik ini merupakan salah satu yang sedang berkembang di masyarakat dikarenakan teknik ini lebih mudah diaplikasikan dan hasilnya lebih bagus dibandingkan sebelumnya yaitu transformasi Fourier. DWT membagi sebuah dimensi sinyal menjadi dua bagian, yaitu frekuensi tinggi (highpass filter) dan frekuensi rendah (lowpass filter). Secara umum penyisipan watermark ke dalam sebuah citra digital dilakukan dengan cara membandingkan koefisien DWT pada rentang frekuensi hasil dekomposisi citra asli, dimana rentang frekuensi yang memiliki nilai koefisien DWT terbesar adalah tempat yang paling signifikan untuk menyisipkan watermark.

Penelitian yang menggunakan teknik watermarking antara lain penelitian oleh Moh Khavid Reza dengan judul Perancangan Sistem Watermarking Pada Citra Digital Menggunakan Metode DCT dan LSB, serta penelitian lain oleh B. Yudi Dwiandiyanta dalam penelitiannya yang berjudul Perbandingan Watermarking Citra dengan Alihragam Wavelet dan Discrete Cosine Transform.

\section{KAJIAN TEORI}

\section{A. Citra Digital}

Citra didefinisikan sebagai fungsi $f(x, y)$ dimana $x$ dan $y$ adalah sebuah koordinat pada bidang dan amplitude dari $f$ pada pasangan koordinat adalah intensitas atau sebuah tingkatan keabu-abuan dari suatu citra pada titik tersebut. Jika $x, y$, dan nilai intensitas dari f tersebut bernilai diskrit, berhingga, citra tersebut dinamakan citra digital [1].

Citra digital dapat diwakili oleh sebuah matriks yang terdiri dari baris $(N)$ dan kolom $(M)$ dimana perpotongan 
antara kolom dan baris disebut pixel, yaitu elemen terkecil dari sebuah citra. Pixel mempunyai dua parameter, yaitu koordinat dan intensitas atau warna. Nilai fungsi $f(x, y)$ pada koordinat citra $(x, y)$ merupakan besar dari intensitas atau warna dari pixel pada titik itu [2].

$$
\begin{aligned}
& \mathrm{N}=\text { jumlah baris } \quad 0 \leq \mathrm{x} \leq \mathrm{N}-1 \\
& \mathrm{M}=\text { jumlah kolom } \quad 0 \leq \mathrm{y} \leq \mathrm{M}-1 \\
& \mathrm{~L}=\text { maksimal warna intensitas } \quad 0 \leq \mathrm{f}(\mathrm{x}, \mathrm{y}) \leq \mathrm{L}-1
\end{aligned}
$$

$$
\begin{aligned}
& f(x, y) \\
& =\left[\begin{array}{cccc}
f(0,0) & f(0,1) & . & f(0, M-1) \\
f(1,0) & f(1,1) & \because & f(1, M-1) \\
\vdots & : & : & : \\
f(N-1,0) & f(N-1,1) & \cdots & f(N-1, M-1)
\end{array}\right]
\end{aligned}
$$

\section{B. Watermarking}

Watermarking merupakan salah satu bentuk dari steganography, yang dapat diartikan sebagai suatu teknik penyembunyian data atau informasi ke dalam suatu data lainnya. Orang lain tidak menyadari kehadirannya. Jadi seolah-olah tidak ada perbedaan signifikan antara citra host dan citra ber-watermark.

Watermark merupakan sebuah informasi yang disisipkan pada media lain dengan tujuan melindungi media yang disisipi oleh informasi tersebut dari pembajakan, penyalahgunaan hak cipta, dan sebagainya, watermarking sendiri adalah cara untuk menyisipkan watermark ke dalam media yang ingin dilindungi hak ciptanya [3].

Adapun manfaat utama secara umum dari watermarking, antara lain [2]:

a. Proteksi Hak Cipta

Tujuan watermark dalam perlindungan hak cipta adalah sebagai bukti otentik atas hak kepemilikan pencipta atas konten yang dibuat atau diproduksinya.

b. Fingerprinting

Tujuan watermark adalah mengidentifikasi setiap penggunaan dan distribusi suatu content.

c. Proteksi terhadap penggandaan (copy protection)

Watermark bermanfaat untuk melindungi konten dari duplikasi dan pembajakan.

d. Autentikasi citra

Watermark bermanfaat dalam proses autentikasi, sehingga modifikasi dari suatu citra dapat terdeteksi.

Jenis watermark berdasarkan persepsi manusia dibagi menjadi dua jenis [2]:

1. Visible Watermarking

Merupakan jenis watermark dapat dilihat oleh panca indra manusia (mata telanjang). Sifat watermark ini sangat kuat bahkan sangat sulit dihapus keberadaannya walaupun tidak menjadi bagian dari image. Sebagai contohnya adalah logo transparan yang biasa diletakkan di pojok-pojok pada hasil foto.

2. Invisible Watermarking

Watermark jenis ini tidak dapat dilihat oleh panca indera, yang bertujuan memberikan informasi yang bersifat rahasia dan untuk melindungi hak cipta orang lain dari orang yang tidak bertanggung jawab. Jenis watermark ini dapat dilihat melalui proses komputasi yaitu dengan cara mengekstrak gambar yang ter-watermark.
Klasifikasi teknik watermarking digital pada saat ini cukup banyak. Ada beberapa teknik watermarking berdasarkan domain kerjanya, yaitu [4]:

1. Teknik watermarking yang bekerja pada domain spasial (spatial domain watermarking).

Teknik ini bekerja dengan cara menyisipkan watermark secara langsung kedalam domain spasial dari suatu citra. Istilah domain spasial sendiri mengacu pada pikselpiksel penyusun sebuah citra. Teknik watermarking jenis ini beroperasi secara langsung pada piksel-piksel tersebut. Beberapa contoh teknik yang bekerja pada domain spasial adalah teknik penyisipan pada Least Significant Bit (LSB).

2. Teknik watermarking yang bekerja pada domain transform (transform domain watermarking).

Pada transform domain watermarking (sering juga disebut dengan frequency domanin watermarking) ini penyisipan watermark dilakukan pada koefisien frekuensi hasil transformasi citra asalnya. Ada beberapa transformasi yang umum digunakan oleh para peneliti, yaitu: Discrete Cosine Transform (DCT), Discrete Fourier Transform (DFT), Discrete Wavelet Transform (DWT) maupun Discrete Laguerre Transform (DLT).

3. Teknik watermarking yang bekerja pada kedua domain diatas (hybrid techniques watermarking).

Teknik watermarking jenis ini bekerja dengan menggabungkan kedua teknik diatas. Pada teknik ini biasanya penanaman watermark dilakukan pada domain frekuensi beberapa bagian citra yang dipilih berdasarkan karakteristik spasial citra tersebut.

\section{Framework Watermarking}

Jika watermark merupakan sesuatu yang disisipkan, maka watermarking merupakan proses penyisipan watermark tersebut. Secara umum framework sebuah algoritma watermarking tersusun atas dua bagian, yaitu algoritma penyisipan watermark (encoder) dan algoritma pendeteksian watermark (decoder). Algoritma penyisipan watermark (encoder) adalah algoritma yang menangani bagaimana sebuah watermark ditanamkan pada media induknya, sedangkan algoritma pendeteksian watermark adalah algoritma yang menentukan apakah di dalam sebuah media digital terdeteksi watermark yang sesuai atau tidak [5].

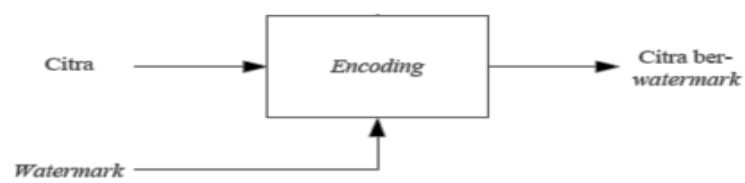

Gambar 1. Proses penyisipan watermark pada citra digital

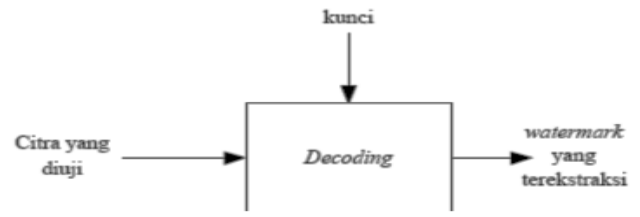

Gambar 2. Proses pendeteksian watermark pada citra digital

Label watermark adalah suatu data/informasi yang akan dimasukkan ke dalam data digital yang ingin di-watermark. Ada 2 jenis label yang dapat digunakan, yakni teks biasa, 
logo atau citra atau suara. Kelemahan dari label teks adalah kesalahan pada satu bit saja dapat menghasilkan hasil yang berbeda dengan teks asli. Sedangkan logo atau citra atau suara, yakni kesalahan pada beberapa bit masih dapat memberikan persepsi yang sama dengan aslinya oleh pendengaran maupun penglihatan kita, tetapi kerugiannya adalah jumlah data yang cukup besar [5].

\section{Transformasi Citra}

Transformasi citra dapat diartikan sebagai perubahan bentuk suatu citra. Perubahan bentuk tersebut dapat berupa perubahan geometri piksel seperti perputaran (rotasi), pergeseran (translasi), penskalaan, dan lain sebagainya atau dapat juga berupa perubahan ruang (domain) citra ke domain lainnya.

Transformasi citra merupakan pokok bahasan yang sangat penting dalam pengolahan citra. Citra hasil proses transformasi dapat dianalisis kembali, diinterprestasikan, dan dijadikan acuan untuk melakukan pemrosesan selanjutnya. Tujuan diterapkannya transformasi citra adalah untuk memperoleh informasi (feature extraction) yang lebih jelas yang terkandung dalam suatu citra.

Melalui proses transformasi, suatu citra dapat dinyatakan sebagai kombinasi linear dari sinyal dasar (basic signals) yang sering disebut dengan fungsi basis (basis fuction). Suatu citra yang telah mengalami transformasi dapat diperoleh kembali dengan menggunakan transformasi balik (invers transformation). Pada transformasi citra terdapat berbagai macam transformasi diantaranya, Fast Fourier Transform (FFT), Discrete Cosine Transform (DCT), Discrete Wavelet Transform (DWT), dan lain-lain [6].

\section{E. Wavelet}

Gelombang (wave) adalah sebuah fungsi yang bergerak naik turun ruang dan waktu secara periodik. Sedangkan wavelet merupakan gelombang yang dibatasi atau dapat dikatakansebagai gelombang pendek. Wavelet mengkonsentrasikan energinya dalam ruang dan waktu sehingga cocok untuk menganalisis sinyal yang sifatnya sementara saja.

Wavelet pertama kali digunakan dalam analisis dan pemrosesan digital dari sinyal gempa bumi, yang tercantum dalam literatur oleh A. Grossman dan J. Morlet. Penggunaan wavelet pada saat ini sudah semakin berkembang dengan munculnya area sains terpisah yang berhubungan dengan analisis wavelet dan teori transformasi wavelet. Dengan munculnya area sains ini wavelet mulai digunakan secara luas dalam filtrasi dan pemrosesan data, pengenalan citra, sintesis dan pemrosesan berbagai variasi sinyal, kompresi dan pemrosesan citra, dan lain-lain [4].

\section{F. Transformasi Wavelet}

Transformasi wavelet adalah sebuah transformasi matematika yang digunakan untuk menganalisis sinyal bergerak. Sinyal bergerak ini dianalisis untuk didapatkan informasi spektrum frekuensi dan waktunya secara bersamaan. Salah satu seri pengembangan transformasi wavelet adalah Discrete Wavelet transform (DWT) [7].

Transformasi sinyal merupakan bentuk lain dari penggambaran sinyal yang tidak mengubah isi informasi dalam sinyal tersebut. Transformasi wavelet (wavelet transform) menyediakan penggambaran frekuensi waktu dari sinyal. Pada awalnya, transformasi wavelet digunakan untuk menganalisis sinyal bergerak (non-stationary signals). Sinyal bergerak ini dianalisis dalam transformasi wavelet dengan menggunakan teknik multi-resolution analysis. Secara umum teknik multi-resolution analysis adalah teknik yang digunakan untuk menganalisis frekuensi dengan cara frekuensi yang berbeda dianalisis menggunakan resolusi yang berbeda. Resolusi dari sinyal merupakan ukuran jumlah informasi di dalam sinyal yang dapat berubah melalui operasi filterisasi [7].

Transformasi wavelet selain mampu memberikan informasi frekuensi yang muncul, juga dapat memberikan informasi tentang skala atau waktu. Wavelet dapat digunakan untuk menganalisis suatu bentuk gelombang (sinyal) sebagai kombinasi dari waktu (skala) dan frekuensi. Selain itu perubahan sinyal pada suatu posisi tertentu tidak akan berdampak banyak terhadap sinyal pada posisi-posisi yang lainnya. Dengan wavelet suatu sinyal dapat disimpan lebih efisien dibandingkan dengan fourier dan lebih baik dalam hal melakukan suatu pendekatan untuk memperoleh nilai yang sedekat mungkin terhadap real-word signal. Transformasi wavelet dibagi menjadi dua bagian besar, yaitu Continuous Wavelet Transform (CWT) dan Discrete Wavelet Transform (DWT) [8].

\section{G. Discrete Wavelet Transform (DWT)}

Transformasi wavelet diskrit atau Discrete Wavelet Transform (DWT) secara umum merupakan dekomposisi citra pada frekuensi subband citra tersebut. Komponen subband transformasi wavelet dihasilkan dengan cara penurunan level dekomposisi. Dalam transformasi wavelet diskrit, penggambaran sebuah skala waktu sinyal digital didapatkan dengan menggunakan teknik filterisasi digital. Secara garis besar proses dalam teknik ini adalah dengan melewatkan sinyal yang akan dianalisis pada filter dengan frekuensi dan skala yang berbeda [7].

Implementasi transformasi wavelet diskrit dapat dilakukan dengan cara melewatkan sinyal ke dalam dua filterisasi DWT yaitu highpass filter (HPF) dan lowpass filter (LPF) agar frekuensi dari sinyal tersebut dapat dianalisis kemudian melakukan downsampling pada keluaran masing-masing filter.

Analisis sinyal dilakukan terhadap hasil filterisasi highpass filter (HPF) dan lowpass filter (LPF) di mana HPF digunakan untuk menganalisis frekuensi tinggi dan LPF digunakan untuk menganalisis frekuensi rendah. Analisis terhadap frekuensi dilakukan dengan cara menggunakan resolusi yang dihasilkan setelah sinyal melewati filterisasi. Analisis frekuensi yang berbeda dengan menggunakan resolusi yang berbeda inilah yang disebut dengan multiresolution analysis [9].

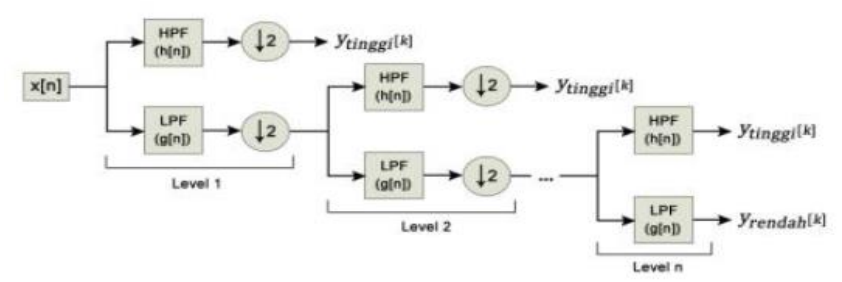

Gambar 3. Dekomposisi Wavelet Diskrit 
Proses dekomposisi ini dapat melalui satu atau lebih tingkatan. Dekomposisi satu tingkat ditulis dengan ekspresi matematika berikut [7]:

$$
\begin{aligned}
& y_{\text {tinggi }}[k]=\sum_{n} x[n] h[2 k-n] \\
& y_{\text {rendah }}[k]=\sum_{n} x[n] g[2 k-n]
\end{aligned}
$$

$y_{\text {tinggi }}[k]$ dan $y_{\text {rendah }}[k]$ yang merupakan hasil dari highpass filter dan lowpassfilter, $x[n]$ merupakan sinyal asal, $h[n]$ adalah highpass filter, dan $g[n]$ adalah lowpass filter. Untuk dekomposisi lebih dari satu tingkat, prosedur pada persamaan (1) dan (2) dapat digunakan pada masingmasing tingkatan [7].

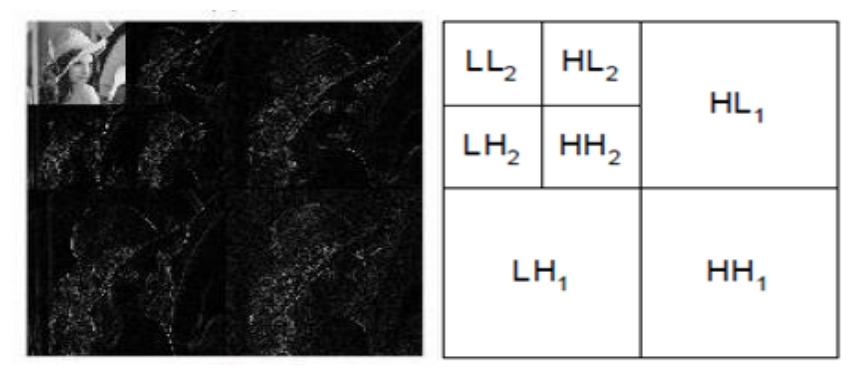

Gambar 4. Transformasi Wavelet Diskrit 2D Level 2

Untuk transformasi citra dua dimensi pada Gambar 4, prosedur dekomposisi level pertama terdiri dari citra satu dimensi yang di-filter pada arah mendatar (baris) kemudian diikuti oleh citra satu dimensi yang di-filter pada arah tegak (kolom) yang diutilisasi dengan menggunakan filter tapis rendah (lowpass filter) dan filter tapis tinggi (highpass filter).

\section{H. Inverse Discrete Wavelete Transform (IDWT)}

Secara umum teknik watermarking dapat dibedakan menjadi dua, yaitu non blind watermarking dan blind watermarking. Non blind watermarking merupakan teknik watermarking yang memerlukan citra host dan citra berwatermark untuk mengekstrak watermark. Sedangkan blind watermarking merupakan teknik watermarking yang tidak memerlukan citra host untuk melakukan ekstraksi. Dalam penelitian ini menggunakan teknik non blind watermarking.

Dengan menggunakan koefisien DWT ini maka dapat dilakukan proses Inverse Discrete Wavelet transform (IDWT) untuk merekonstruksi menjadi sinyal asal melalui persamaan berikut [7]:

$$
x[n]=\sum_{k}\left(y_{\text {tinggi }}[k] h[-n+2 k] y_{\text {rendah }}[k] g[-n+\right.
$$$$
2 k] \text { ) }
$$

Proses rekontruksi merupakan kebalikan dari proses dekomposisi sesuai dengan tingkatan pada proses dekomposisi. DWT menganalisis sinyal pada frekuensi berbeda dengan resolusi yang berbeda melalui dekomposisi sinyal sehingga menjadi detil informasi dan taksiran kasar. DWT bekerja pada dua kumpulan fungsi yang disebut fungsi penskalaan dan fungsi wavelet yang masing- masing berhubungan dengan lowpass filter dan highpass filter.

Proses rekonstruksi ini sepenuhnya merupakan kebalikan dari proses dekomposisi sesuai dengan tingkatan pada proses dekomposisi, yang mana untuk setiap rekonstruksi pada masing-masing tingkatan dapat menggunakan persamaan matematika. Proses rekonstruksi wavelet untuk mendapatkan sinyal asal ditunjukkan pada gambar berikut:

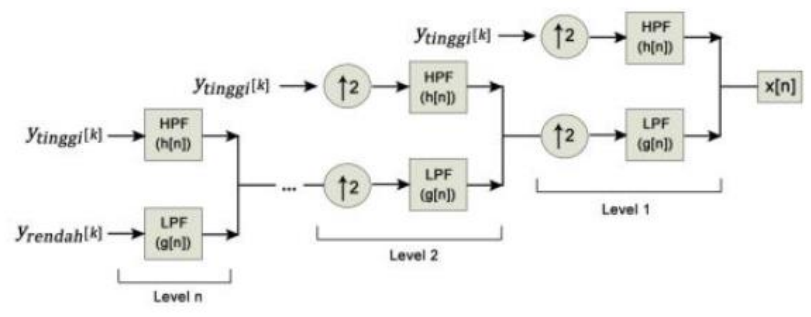

Gambar 5. Rekonstruksi Wavelet Diskrit 1 Dimensi

\section{PSNR}

Peak Signal-to-Noise Ratio (PSNR) adalah salah satu metode yang cukup populer digunakan dalam pengukuran kualitas video maupun citra secara objektif. Metode ini menggunakan sinyal citra sebagai parameter objektif. Metode ini membandingkan antara kualitas citra yang telah disisipi watermark (citra ber-watermark) dengan citra asal (citra host). Menurut Syahbana, dkk, PSNR dirumuskan sebagai berikut [10] :

$$
P S N R=10 . \log _{10}\left(\frac{2^{M}-1}{M S E}\right)^{2}
$$

Dimana, 2M-1 adalah maksimum nilai piksel untuk M-bit citra. MSE merupakan kepanjangan dari Mean Square Error. Sebagai contoh, untuk citra dengan resolusi (x,y) piksel, maka MSE didefinisikan dalam persamaan berikut [10]:

$M S E=\frac{1}{X Y T} \sum_{t=1}^{T} \sum_{y=1}^{Y} \sum_{x=1}^{X}\left[i(x, y, t)-i^{\prime}(x, y, t)\right]^{2}$

dengan:

$X=$ panjang/baris;

$Y=$ lebar/kolom;

$T=$ banyaknya layer citra host $(\mathrm{RGB})$;

$i=$ matriks citra awal / citra host;

$i^{\prime}=$ matriks citra hasil / citra ber-watermark

Interpretasi nilai PSNR terhadap kualitas citra dapat dikatakan baik sekali jika nilai PSNR lebih besar dari $33 \mathrm{~dB}$ dan dikatakan buruk jika nilai PSNR kurang dari $30 \mathrm{~dB}$ [10].

\section{METODOLOGI PENELITIAN}

\section{A. Studi Literatur}

Pada tahap ini dilakukan pengumpulan bahan-bahan referensi yang menunjang proses penelitian, yaitu yang berhubungan dengan Invisible watermarking.

\section{B. Analisis}

Analisis yang dibahas meliputi penyisipan watermark dan ekstraksi watermark.

\section{1) Proses Penyisipan Watermark pada Citra Digital}

Langkah-langkah yang dilakukan dalam proses ini, sebagaimana yang terlihat pada Gambar 1 .

a. Pemilihan citra host dan citra watermark, jenis citra yang dapat digunakan adalah citra RGB dengan ukuran citra watermark $\leq$ citra host.

b. Proses dekomposisi citra host menggunakan DWT. Proses dekomposisi ini dilakukan dengan DWT2 keluarga haar. Dekomposisi citra digital menghasilkan LL, LH, HL, dan HH. Sama halnya dengan citra host, 
citra watermark ini didekomposisi menggunakan DWT keluarga haar.

c. Setelah citra host dan citra watermark didekomposisi dalam DWT, citra watermark disisipkan ke dalam rentang frekuensi LL.

d. Menyisipkan $w$ ke dalam rentang frekuensi LL :

$\mathrm{f}^{\prime}{ }_{L L}(\mathrm{~m}, \mathrm{n})=f_{L L}(\mathrm{~m}, \mathrm{n})+\alpha \cdot w_{L L}(\mathrm{~m}, \mathrm{n})$

dengan $\mathrm{m}, \mathrm{n}=1, \ldots, \mathrm{L}$

Dimana $\mathrm{f}_{\mathrm{LL}}(\mathrm{m}, \mathrm{n})$ merupakan koefisien yang dipilih, $\alpha$ merupakan kekuatan penyisipan watermark atau dapat dikatakan sebagai faktor skala persentase dari citra host dan citra watermark pada citra ber-watermark yang dibentuk.

e. Menjalankan Inverse Discrete Wavelet Transform (IDWT) untuk membentuk citra ber-watermark.

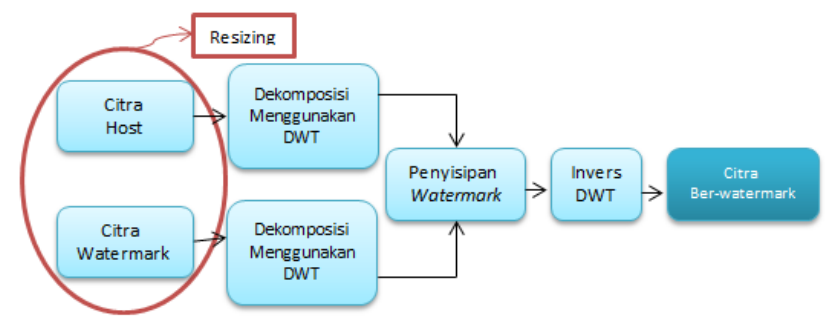

Gambar 5. Proses Penyisipan Watermark

\section{2) Proses Rekonstruksi Watermark pada Citra Digital}

Langkah - langkah rekonstruksi watermark adalah :

a. Citra ber-watermark didekomposisi dalam DWT.

b. Memilih frekuensi LL dari hasil DWT.

c. Melakukan pengurangan frekuensi LL citra berwatermark dengan frekuensi LL citra host untuk menghasilkan frekuensi LL citra watermark.

d. Menjalankan Inverse Discrete Wavelet Transform (IDWT) untuk membentuk citra watermark.

Secara umum proses rekonstruksi watermark ini merupakan kebalikan dari proses penyisipan watermark.

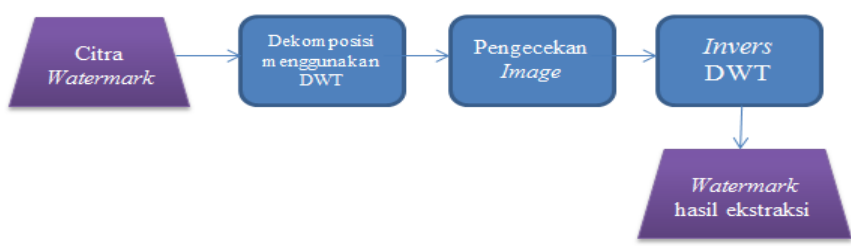

Gambar 6. Proses Rekonstruksi Watermark

\section{Implementasi}

Pada tahap ini dilakukan implementasi (pengkodean) berdasarkan rancangan yang dilakukan pada tahap sebelumnya. Dibangun suatu aplikasi watermarking menggunakan metode Invisible Watermarking pada domain DWT. Modul yang dibangun meliputi proses penyisipan dan ekstraksi. Bahasa pemrograman yang digunakan pada tahap implementasi ini yaitu bahasa pemrograman Matlab R2013a.

\section{Pengujian}

Pada tahap ini akan dilakukan pengujian terhadap metode yang digunakan, untuk mengetahui kualitas dari metode ini akan dilakukan pengujian PSNR. Pengujian PSNR ini dilakukan pada citra yang telah disisipi watermark (citra ber-watermark), yaitu dengan membandingkan citra berwatermark dengan citra host.

Pengujian kedua dilakukan untuk mengetahui ketahanan metode ini terhadap noise. Untuk mengetahui ketahanan metode terhadap noise, maka akan diberi noise pada citra ber-watermark, selanjutnya akan direkonstruksi.

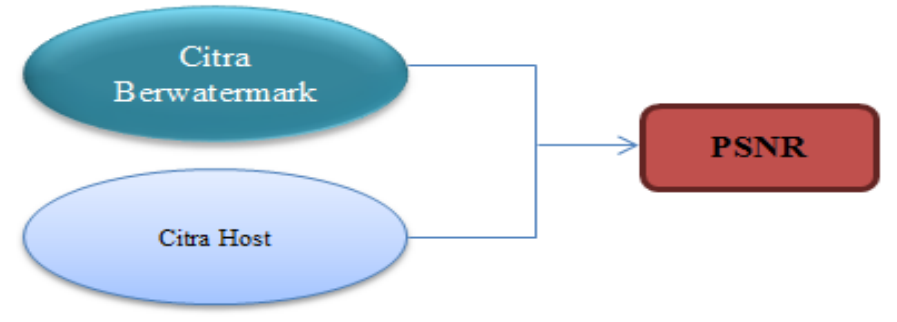

Gambar 6. Proses Pengujian

\section{E. Penarikan Kesimpulan}

Pada tahap ini adalah penarikan kesimpulan berdasarkan tabel dari hasil pengujian dan pemberian saran terkait kekurangan hasil penelitian untuk pengembangan berikutnya.

\section{F. Penulisan Studi}

Pada tahap terakhir ini akan dibuat laporan dari hasil penelitian yang telah dilakukan pada tahap-tahap sebelumnya.

\section{PENGUJIAN DAN PEMBAHASAN}

Pada bab ini akan dilakukan pengujian serta pembahasan terhadap program yang telah dibuat. Pengujian sistem ini merupakan pengujian invisible watermarking pada citra berwarna RGB dalam format file BMP, PNG atau JPG. Pada bagian awal adalah hasil uji coba terhadap citra yang belum dikenai serangan, kemudian dilanjutkan terhadap citra yang dikenakan serangan. Pengujian dilakukan untuk mendapatkan nilai MSE, PSNR dan ekstraksi watermark.

\section{A. Data Uji Coba}

Uji coba pada program dalam penelitian tugas akhir ini dilakukan pada citra host dan citra watermark dengan varian citra yaitu, citra dengan warna yang ekstrim beda, citra dengan warna yang hampir sama, dan citra dengan warna yang biasa-biasa. Hal ini didapat dengan menggunakan standar deviasi, jadi semakin besar standar deviasinya semaikin berbeda tiap citranya. Jadi ada sembilan percobaan.

Tabel 1

Tabel Citra Host yang Digunakan.

\begin{tabular}{ccccc}
\hline \hline No & Nama file & $\begin{array}{c}\text { Ukuran } \\
\text { citra }\end{array}$ & Varian citra & Citra \\
\hline 1 & Baboon.png & $\begin{array}{c}512 \times 512 \\
\text { pixel }\end{array}$ & $\begin{array}{c}\text { Standar } \\
\text { deviasi } \\
\text { tinggi }\end{array}$ &
\end{tabular}

$\begin{array}{ccc}\text { Lena. } & \begin{array}{c}512 \times 512 \\ \text { jpg }\end{array} & \begin{array}{c}\text { Standar } \\ \text { pixel }\end{array} \\ \text { miasi rata- } \\ \text { rata/ } \\ \text { mengah }\end{array}$




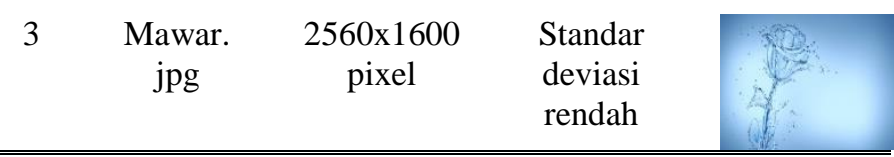

Tabel 2

Tabel Citra Watermark yang Digunakan.

\begin{tabular}{ccccc}
\hline \hline No & Nama file & Ukuran citra & Varian citra & Citra \\
\hline 1 & $\begin{array}{c}\text { Orange. } \\
\text { jpg }\end{array}$ & $\begin{array}{c}472 \times 640 \\
\text { pixel }\end{array}$ & $\begin{array}{c}\text { Standar } \\
\text { deviasi tinggi }\end{array}$ \\
2 & $\begin{array}{c}\text { World } \\
\text { wide.jpg }\end{array}$ & $\begin{array}{c}809 \times 360 \\
\text { pixel }\end{array}$ & $\begin{array}{c}\text { Standar } \\
\text { deviasi rata- } \\
\text { rata/ }\end{array}$ \\
& Unenengah & \\
3 & Ubur2. & $\begin{array}{c}\text { 1140x550 } \\
\text { pixel }\end{array}$ & $\begin{array}{c}\text { Standar } \\
\text { deviasi } \\
\text { rendah }\end{array}$ & \\
\hline \hline
\end{tabular}

\section{B. Pengujian Hasil Watermark}

Untuk proses penyisipan watermark akan resize terlebih dahulu citra yang digunakan untuk penyisipan watermark (citra host) yang ditampilkan pada Tabel 1 dan citra untuk watermark (citra watermark) yang ditampilkan pada Tabel 2. Selanjutnya citra hasil penyisipan (citra ber-watermark) akan dibandingkan dengan citra host untuk mendapatkan nilai MSE dan PSNR. Setelah itu, akan dilakukan proses rekonstruksi untuk mendapatkan watermark hasil ekstraksi.

\section{Pengujian PNSR (Peak Signal to Noise Ratio)}

Pengujian PSNR ini dilakukan pada citra yang telah disisipi watermark (citra ber-watermark), yaitu dengan membandingkan citra ber-watermark dengan citra host. Untuk mendapatkan nilai PSNR, kita harus menghitung terlebih dahulu nilai Mean Squared Error (MSE) dari suatu citra ber-watermark.

Tabel 3

Tabel Nilai MSE dan PSNR dari Hasil Pengujian.

\begin{tabular}{|c|c|c|c|c|}
\hline \multirow{2}{*}{ No } & \multirow{2}{*}{ File Name } & \multicolumn{3}{|c|}{ PSNR } \\
\hline & & Level 1 & Level 2 & Level 3 \\
\hline 1 & Uji 1 & 33.3545 & 33.4293 & 33.5541 \\
\hline 2 & Uji 2 & 28.8816 & 28.9113 & 28.9546 \\
\hline 3 & Uji 3 & 30.3474 & 30.381 & 30.4152 \\
\hline 4 & Uji 4 & 32.7328 & 32.8076 & 32.9324 \\
\hline 5 & Uji 5 & 28.2598 & 28.2895 & 28.3329 \\
\hline 6 & Uji 6 & 29.7257 & 29.7593 & 29.7935 \\
\hline 7 & Uji 7 & 33.3624 & 33.4372 & 33.562 \\
\hline 8 & Uji 8 & 28.8895 & 28.9192 & 28.9625 \\
\hline 9 & Uji 9 & 30.3553 & 30.3889 & 30.4231 \\
\hline & Rata-rata & 29.9107 & 29.9464 & 29.9912 \\
\hline
\end{tabular}

Tabel 4

Tabel Waktu berdasarkan Levelnya.

\begin{tabular}{|c|c|c|c|c|}
\hline \multirow{2}{*}{ No } & \multirow{2}{*}{ File Name } & \multicolumn{3}{|c|}{ Waktu } \\
\hline & & Level 1 & Level 2 & Level 3 \\
\hline 1 & Uji 1 & 0.0753 & 0.0757 & 0.1129 \\
\hline 2 & Uji 2 & 0.0535 & 0.0761 & 0.0964 \\
\hline 3 & Uji 3 & 0.0518 & 0.0754 & 0.0938 \\
\hline 4 & Uji 4 & 0.0529 & 0.0773 & 0.1272 \\
\hline 5 & Uji 5 & 0.0578 & 0.0727 & 0.1015 \\
\hline 6 & Uji 6 & 0.0489 & 0.0759 & 0.0979 \\
\hline 7 & Uji 7 & 0.0553 & 0.0824 & 0.0954 \\
\hline 8 & Uji 8 & 0.053 & 0.0759 & 0.1756 \\
\hline 9 & Uji 9 & 0.0511 & 0.0798 & 0.0939 \\
\hline & Rata-rata & 0.0476 & 0.0792 & 0.1218 \\
\hline
\end{tabular}

\section{Pengujian Ketahanan Terhadap Noise}

Pengujian terhadap kehandalan / ketahanan dari citra berwatermark dapat dilakukan dengan memberi serangan (noise). Ada empat macam noise yang digunakan dalam penelitian ini, yaitu noise Poisson, noise Gaussian, noise Salt \& Pepper, dan noise Speckle.

\section{E. Analisis Hasil Pengujian}

Hasil pengujian sistem, dengan menggunakan variasi warna citra pada DWT2, dapat menghasilkan citra berwatermark sebagai hasil proses penyisipan watermark yang tidak berebeda jauh dengan citra host-nya. Hal ini dibuktikan dengan skala nilai PSNR sekitar 30 yang merupakan nilai PSNR yang tergolong baik.

Hasil dari pengujian ketahanan metode ini terhadap noise masih tergolong kurang baik, hal ini bisa dilihat dari hasil rekonstruksi watermark yang dilakukan setelah citra berwatermark diberi noise.

Hasil dari pengujian noise bahwa semakin kecil nilai parameter noise, maka semakin bagus kualitas citra atau semakin tinggi ketahanan citra terhadap noise. Selain itu, semakin tingginya standar deviasi citra host dan citra watermark maka semakin tahan citra terhadap noise. Ketiga, semakin tingginya level dekomposisi, maka semakin tinggi juga ketahanan citra terhadap noise.

\section{KESIMPULAN}

Berdasarkan analisis terhadap hasil pengujian yang telah dilakukan pada teknik invisible watermarking digital menggunakan metode descrete wavelet transform, maka dapat diambil beberapa kesimpulan sebagai berikut:

1. Dekomposisi citra digital menggunakan Discrete Wavelet Transform (DWT) dalam tugas akhir ini telah berhasil dilakukan dengan cara mengambil koefisien wavelet dari citra tersebut, koefisien wavelet juga yang 
digunakan untuk dapat merekonstruksi citra kembali menggunakan Inverse Discrete Wavelet Transform (IDWT).

2. Aplikasi watermarking yang telah dibuat memiliki tingkat invisibility yang bagus, artinya watermark yang disisipkan tidak terlihat, hal ini dapat dibuktikan dengan nilai PSNR yang cukup tinggi.

3. Aplikasi watermarking yang telah dibuat juga memiliki tingkat readibility, artinya hal ini dapat dilihat dari perbandingan citra watermark dengan citra watermark hasil rekonstruksi, dan citra berwateramark dengan citra host.

4. Karena pada proses penyisipan citra host dan citra watermark serta proses uji noise yang menggunakan parameter, maka dapat ditarik kesimpulan terhadap nilai parameter. Semakin kecil nilai parameter, maka semakin bagus kualitas citra digital pada proses penyisipan atau semakin tinggi ketahanan citra digital terhadap noise.

5. Dekomposisi citra digital yang menggunakan DWT2 dalam tugas akhir ini adalah pada level 1, level 2, dan level 3. Semakin tingginya level dekompisisi, maka semakin tinggi juga kualitas citra digital dan ketahanan citra digital terhadap noise.

\section{DAFTAR PUSTAKA}

[1] R. Gonzalez, R.C., E.W., Digital Image Processing. United State of America: Prentice-Hall. Inc, 2008.

[2] W. Sutoyo T, Mulyanto E, Suhartono V, Nurhayati O. D, Teori Pengolahan Citra Digital. Yogyakarta: Andi, 2009.

[3] R. Munir, "Sekilas Image Watermarking untuk Memproteksi Citra Digital dan Aplikasinya pada Citra Medis," Institut Teknologi Bandung, 2006.

[4] N. Tuakia, N.M., Suprapto, \& Yudistira, "Implementasi Watermarking Pada Citra Medis Menggunakan Metode Discrete Wavelet Transform (DWT)," Universitas Brawijaya.

[5] W. Wong, Ny poi., \& Cahyadi, "Rancang Bangun Aplikasi Watermarking Pada Gambar Dengan Algoritma Digital Semipublic," 2012.

[6] D. Putra, Pengolahan Citra Digital. Yogyakarta: Andi, 2010.

[7] Alfatwa, Watermarking Pada Citra Digital Menggunakan Discrete Wavelet Transform. Bandung: Institute Teknologi Bandung, 2009.

[8] M. F. A. P. P. Kutter, "A Fair Benchmark for Image Watermarking Systems," Int. Soc. Opt. Eng., 1999.

[9] A. R. Hakim, "Analisa Perbandingan Watermarking Image Menggunakan Discrete Wavelet Transform," Universitas Indonesia, 2012.

[10] D. Syahbana, Yoanda Alim, "Algoritma Penyisipan Frame untuk Peningkatan Akurasi Metode Aligned Peak Signal-to-Noise Ratio dalam Pengukuran Kualitas Video," J. Komput. Terap., vol. 1, no. $2,2015$. 